\title{
Presence or absence of carbohydrates and the proportion of fat in a high-protein diet affect appetite suppression but not energy expenditure in normal-weight human subjects fed in energy balance
}

\author{
Margriet A. B. Veldhorst ${ }^{1,2} *$, Klaas R. Westerterp ${ }^{1,2}$, Anneke J. A. H. van Vught ${ }^{1,2}$ \\ and Margriet S. Westerterp-Plantenga ${ }^{1,2}$ \\ ${ }^{1}$ Department of Human Biology, NUTRIM School for Nutrition, Toxicology and Metabolism, Maastricht University Medical Centre, \\ PO Box 616, 6200 MD Maastricht, The Netherlands \\ ${ }^{2}$ Top Institute Food and Nutrition, Wageningen, The Netherlands
}

(Received 18 September 2009 - Revised 7 April 2010 - Accepted 21 April 2010 - First published online 22 June 2010)

\begin{abstract}
Two types of relatively high-protein diets, with a normal or low proportion of carbohydrates, have been shown effective for weight loss. The objective was to assess the significance of the presence or absence of carbohydrates and the proportion of fat in high-protein diets for affecting appetite suppression, energy expenditure, and fat oxidation in normal-weight subjects in energy balance. Subjects (aged 23 (SD 3) years and BMI 22.0 $(\mathrm{SD} 1.9) \mathrm{kg} / \mathrm{m}^{2}$ ) were stratified in two groups. Each was offered two diets in a randomised cross-over design: group 1 ( $n$ 22) - normal protein (NP; 10, 60 and $30 \%$ energy (En\%) from protein, carbohydrate and fat), high protein (HP; 30, 40 and 30 En\%); group 2 ( $n$ 23) - normal protein (NP-g; 10, 60 and $30 \mathrm{En \%}$ ), high protein, carbohydrate-free (HP-0C; 30, 0 and 70 En\%) for $2 \mathrm{~d}$; NP-g and HP-0C were preceded by glycogenlowering exercise (day 1). Appetite was measured throughout day 2 using visual analogue scales (VAS). Energy expenditure (EE) and substrate oxidation (respiratory quotient; RQ) were measured in a respiration chamber (08.00 hours on day 2 until 07.30 hours on day 3). Fasting plasma $\beta$-hydroxybutyrate (BHB) concentration was measured (day 3). NP-g and NP did not differ in hunger, EE, RQ and BHB. HP-0C and HP $v$. NP-g and NP, respectively, were lower in hunger $(P<0.05 ; P<0.001)$ and RQ $(P<0.01 ; P<0.001)$ and higher in EE $(P<0.05 ; P=0.07)$ and $\mathrm{BHB}$ $(P<0.05 ; P<0.001)$. Hunger and RQ were lower with HP-0C than HP (693 (SD 208) v. 905 (SD 209) mm VAS $\times 24 \mathrm{~h}, P<0.01 ; 0.76$ (SD 0.01) v. 0.81 (SD 0.02), $P<0.01$ ); BHB was higher (1349 (SD 653) v. 332 (SD 102) $\mu \mathrm{mol} / 1 ; P<0 \cdot 001$ ). $\Delta$ Hunger, $\Delta \mathrm{RQ}$, and $\Delta \mathrm{BHB}$ were larger between HP-0C-NP-g than between HP-NP (-346 (SD 84) v. -107 (SD 52) mm VAS $\times 24 \mathrm{~h}, P<0.01 ;-0.09$ (SD 0.00) $v .-0.05$ (SD 0.00), $P<0.001 ; 1115$ (SD 627) v. 104 (SD 42) $\mu \mathrm{mol} / \mathrm{l}, P<0.001$ ). In conclusion, appetite suppression and fat oxidation were higher on a high-protein diet without than with carbohydrates exchanged for fat. Energy expenditure was not affected by the carbohydrate content of a high-protein diet.
\end{abstract}

Appetite: Carbohydrates: High-protein diets: Energy expenditure

Two types of relatively high-protein diets, i.e. with a relatively normal $^{(1-6)}$ or a relatively low ${ }^{(7-18)}$ proportion of carbohydrates, have been shown to be successful for body-weight loss and weight maintenance. The proportion of protein in these diets ranged from 20 to $40 \%$ of energy (En\%), whereas the proportion of carbohydrates ranged from 4 to 50 En\% ${ }^{(1-18)}$. Diets with less than 38 En\% from carbohydrates have been claimed to be low-carbohydrate diets and are indicated to be ketogenic ${ }^{(7-18)}$. However, in order to be effectively ketogenic, a diet should contain less than $20 \mathrm{~g}$ or, depending on energy intake, only 2-6 En\% from carbohydrates $^{(19,20)}$. Because the maximal protein content in a high-protein diet in energy balance is limited to about $30 \%$ of energy ${ }^{(21)}$, the proportion of fat in a high-protein, low-carbohydrate diet always will be relatively high.
Many favourable results have been published with respect to body-weight loss after high-protein, low-carbohydrate, high-fat diets, i.e. weight losses of 4.5 to $12.0 \mathrm{~kg}$ compared with 2.5 to $6.5 \mathrm{~kg}$ after control diets in 2 to 6 months have been reported ${ }^{(7,9,14,16,17)}$. After diets relatively high in protein but with normal carbohydrate content, body-weight loss after 2 to 6 months ranged from 4.9 to $8.9 \mathrm{~kg}$ compared with 3.4 to $6 \cdot 9 \mathrm{~kg}$ after control diets ${ }^{(1,2,5,6)}$. Moreover, Johnstone et al. showed that weight loss was larger after a high-protein, low-carbohydrate, high-fat diet than after a high-protein, normal-carbohydrate diet for 4 weeks $(6.34 v .4 .35 \mathrm{~kg})^{(18)}$. In addition, a large meta-analysis also showed that high-protein, low-carbohydrate, high-fat diets increased body-weight loss compared with control diets ${ }^{(22)}$. Thus, high-protein, low-carbohydrate, high-fat diets may be more

Abbreviations: EN\%, percentage of energy; group 1, diets HP and NP; group 2, diets HO-0C and NP-g; HP, high-protein; HP-0C, high-protein, carbohydrate-free; $\mathrm{NP}$, normal-protein group 1; NP-g, normal-protein group 2 (with glycogen-lowering); RQ, respiratory quotient; VAS, visual analogue scale; W max, maximal power output.

* Corresponding author: Dr Margriet Veldhorst, fax +31 43 3670976, email m.veldhorst@hb.unimaas.nl 
effective in reducing body weight up to 6 months than high-protein diets with normal carbohydrate content. Several studies with subjects in energy balance under well-controlled conditions have shown that high-protein diets in general affect the metabolic targets appetite suppression, energy expenditure and fat oxidation ${ }^{(23-25)}$. The metabolic targets that are suggested to be affected by relatively high-protein, low-carbohydrate, high-fat diets and are hypothesised to contribute to a reduction in body weight are suppression of appetite, increase in energy expenditure and/or increase of fat oxidation ${ }^{(1-18)}$. However, effects of these diets on these metabolic targets have not been compared under controlled conditions. Therefore, it is not known which of these metabolic targets are especially affected by the absence of carbohydrates and a high fat content in a high-protein diet.

Appetite, energy expenditure, fat oxidation and body composition are affected by obesity, negative energy balance and/or weight loss, therefore, effects of diet composition on these metabolic targets may be confounded by obesity or negative energy balance. In order to actually study effects of the macronutrient composition of the diets on the metabolic targets under highly controlled conditions, we studied normal-weight subjects in energy balance while staying in a respiration chamber. The objective of the present study was to assess the significance of the presence or absence of a normal proportion of carbohydrates and differences in the proportion of fat in a relatively high-protein diet for affecting appetite suppression, energy expenditure, and fat oxidation, measured in a controlled setting in a respiration chamber with normal-weight subjects in energy balance.

\section{Subjects and methods}

\section{Subjects}

Forty-five healthy volunteers (twenty men and twenty-five women, BMI $18 \cdot 5-25 \mathrm{~kg} / \mathrm{m}^{2}$, aged $18-40$ years) were recruited by advertisements placed on notice boards at the university. All subjects underwent a medical screening procedure and were in good health, non-smokers, not using medication and at most moderate alcohol users (ten or less alcoholic consumptions per week). After medical screening subjects were randomly stratified in two groups based on sex, age and BMI; there were no statistically significant differences between the groups (Table 1). The present study was conducted according to the guidelines laid down in the Declaration of Helsinki and all procedures involving human subjects were approved by the Medical Ethics Committee of the Maastricht University Medical Centre. Written informed consent was obtained from all participants. Subjects received financial compensation for participation in the study. The study was conducted from January 2006 until December 2008.

\section{Experimental sessions}

Protocol. Subjects were stratified in two groups. In both groups, subjects were offered two different diets while staying in a respiration chamber for $36 \mathrm{~h}$ ( 20.00 hours on day 1 until 08.00 hours on day 3 ). The first $12 \mathrm{~h}$ of the $36 \mathrm{~h}$ period were considered as baseline measurements to familiarise the
Table 1. Subject characteristics of the subjects stratified in group 1 (normal-protein diet and high-protein diet) and group 2 (normal-protein diet and high-protein, carbohydrate-free diet, both preceded by glycogen lowering)*

(Mean values and standard deviations)

\begin{tabular}{|c|c|c|c|c|}
\hline & \multicolumn{2}{|c|}{ Group 1 (n 22) } & \multicolumn{2}{|c|}{ Group 2 (n 23) } \\
\hline & Mean & SD & Mean & $\mathrm{SD}$ \\
\hline Male $(n)$ & \multicolumn{2}{|c|}{10} & \multicolumn{2}{|c|}{10} \\
\hline Female $(n)$ & \multicolumn{2}{|c|}{12} & \multicolumn{2}{|c|}{13} \\
\hline Age (years) & 23 & 3 & 23 & 2 \\
\hline Height (m) & $1 \cdot 75$ & 0.08 & $1 \cdot 74$ & 0.08 \\
\hline Weight (kg) & 66.9 & $8 \cdot 3$ & $67 \cdot 1$ & $10 \cdot 3$ \\
\hline BMI $\left(\mathrm{kg} / \mathrm{m}^{2}\right)$ & $21 \cdot 7$ & 1.5 & $22 \cdot 2$ & $2 \cdot 3$ \\
\hline Body fat (\%) & $20 \cdot 3$ & $3 \cdot 1$ & 22.9 & $6 \cdot 7$ \\
\hline
\end{tabular}

* Body composition was determined using hydrodensitometry and the ${ }^{2} \mathrm{H}$ dilution technique and was subsequently calculated using the equation of Siri ${ }^{(40)}$. There were no differences between the two groups.

subjects with the respiration chamber. The data of the last $24 \mathrm{~h}$ were included for analyses. The sessions were conducted 4 weeks apart to preclude influences of the menstrual cycle. Subjects were instructed to refrain from heavy exercise for $2 \mathrm{~d}$ before the study and not to consume more than two glasses of alcohol $2 \mathrm{~d}$ before the study. The day before the study the subjects were provided with meals and fed according to the study diet. Group 1 received a high-protein diet and a normal-protein diet (HP and NP; see Diets and energy intake) in a single-blind, randomised, cross-over design. Group 2 received a high-protein, carbohydrate-free diet and a normal-protein diet (HP-0C and NP-g; see Diets and energy intake) in a single-blind, randomised, cross-over design, both preceded by a glycogen-lowering exercise test that took place at 17.00 hours on day 1 , in order to mimic the long term effects of a low-carbohydrate diet that depletes glycogen stores to a great extent ${ }^{(26)}$. This glycogen-lowering exercise test has been shown before not to affect energy expenditure or respiratory quotient $(\mathrm{RQ})^{(27)}$; however, an effect on appetite has been shown by Melanson et al. ${ }^{(28)}$. Therefore, in the present study potential effects of the exercise test on appetite ratings and $\beta$-hydroxybutyrate were controlled for by including the NP-g diet condition. In order to limit the burden of the subjects, a study with two similar groups each receiving two diets was chosen.

A fasting blood sample was taken at the end of each session to measure the concentration of $\beta$-hydroxybutyrate in plasma (08.00 hours on day 3$)$. Ketone bodies, of which $\beta$-hydroxybutyrate is the most important in the blood, are produced when whole-body metabolism shifts towards obtaining a greater percentage of energy from lipid sources by a larger fat oxidation when carbohydrate availability is low and fat is available $\mathrm{e}^{(19)}$.

At the first experimental session body composition was determined.

Diets and energy intake. Group 1 received a diet with 30, 40 and 30 En\% from protein, carbohydrate and fat (HP) and a diet with 10, 60 and 30 En\% from protein, carbohydrate and fat (NP). Here, the effects of a relatively high and normal proportion of protein were compared while fat was kept constant and the proportion of carbohydrates was within the normal range of $40-60 \mathrm{En}{ }^{(29)}$. Group 2 received a diet 
with 30, 0 and 70 En\% from protein, carbohydrate and fat (HP-0C) and a diet with 10, 60 and 30 En\% from protein, carbohydrate and fat (NP-g). The proportion of protein was the same as in the diets of group 1; however, the HP-0C diet did not contain any carbohydrates and had a high fat content. Subjects performed a glycogen-lowering exercise test.

Subjects were fed with a study diet designed to provide energy balance. For the meals that subjects consumed before the experimental sessions at home, the energy content was based on BMR which was calculated with the equation of Harris-Benedict and multiplied with an activity index of 1.7 , which is the average value reported for the general population in The Netherlands ${ }^{(30,31)}$. In order to reach the required macronutrient compositions, amounts of the foods to be served were calculated accordingly subject-specifically. The macronutrient composition of the diets and the average macronutrient intake and energy density are presented in Table 2. During the screening visit it was tested whether the subjects liked all food items sufficiently. Dietary fibre intake was 18.6 (SD 3.1), 20.4 (SD 2.9), 6.1 (SD 1.8), 20.4 (SD 2.9) g/d in the HP, NP, HP-0C and the NP-g conditions, respectively.

To determine the appropriate level of energy intake for attaining energy balance in the respiration chamber, the sleeping metabolic rate was measured during the first night of the first experimental session and multiplied by an activity index of 1.4, which represents an average value for subjects in a respiration chamber ${ }^{(32)}$. Energy intake was divided over the meals as $20 \%$ for breakfast (08.00 hours), $40 \%$ for lunch (13.00 hours) and $40 \%$ for dinner (18.00 hours). Subjects were instructed to finish meals within $20 \mathrm{~min}$; on average they finished their meals within $15 \mathrm{~min}$.

Glycogen-lowering exercise test. Before the HP-0C and the NP-g diet, subjects performed a glycogen-lowering exercise test on an electronically braked cycle ergometer (Lode Excalibur, Groningen, The Netherlands) in the afternoon of day 1. Before, at the screening visit, subjects performed an incremental exhaustive exercise test according to the protocol of Kuipers et al. on an electronically braked cycle ergometer to determine maximal power output $\left(\mathrm{W}_{\max }\right)^{(33)}$, which was 258 (SD 50) W. After a warming-up at $50 \%$ of their $\mathrm{W}_{\max }$ for $5 \mathrm{~min}$, subjects cycled for $2 \mathrm{~min}$ at $90 \%$ of their $\mathrm{W}_{\max }$ followed by $2 \mathrm{~min}$ at $50 \%$ of their $\mathrm{W}_{\text {max }}$; this was repeated until subjects were no longer able to maintain the high-intensity exercise. The maximal intensity was then lowered to $80 \%$ of $\mathrm{W}_{\max }$. When this intensity also could no longer be maintained, the maximal intensity was decreased to $70 \%$ of $\mathrm{W}_{\text {max }}$. The test was ended after exhaustion $^{(27)}$. Subjects were allowed to consume water during the exercise test. Heart rate was monitored continuously during the exercise with a Polar Sport tester (Polar, Kempele, Finland).

Appetite profile. Appetite profile was measured using $100 \mathrm{~mm}$ visual analogue scales (VAS), with the questions 'How hungry are you?' and 'How full do you feel?' that were anchored with 'not at all' and 'extremely'. Subjects were instructed to rate themselves by marking the scale at the point that was most appropriate to their feeling at that time. Questionnaires were completed during each experimental session at 07.55, 08.30, 09.00, 09.30, 10.00, 11.00, 12.00, $12.55,13.30,14.00,14.30,15.00,16.00,17.00,17.55,18.30$,
$19.00,19.30,20.00,21.00$ and 22.00 hours on day 2. For the calculation of the $24 \mathrm{~h}$ area under the curve (AUC) the VAS ratings were interpolated from the latest measurement at night until the first measurement in the morning ${ }^{(34)}$.

Energy expenditure and substrate oxidation. $\mathrm{O}_{2}$ consumption and $\mathrm{CO}_{2}$ production were measured in the respiration chamber $^{(35)}$. This is a $14 \mathrm{~m}^{3}$ room furnished with a bed, chair, computer, television, DVD player, telephone, intercom, sink and toilet. The room was ventilated with fresh air at a rate of 70-80 litres/min. The ventilation rate was measured using electronically modified dry gas meters (G6; Schlumberger, Dordrecht, The Netherlands). The analysis system consisted of dual pairs of IR $\mathrm{CO}_{2}$ (ABB/Hartman\&Braun Uras, Frankfurt am Main, Germany) and paramagnetic $\mathrm{O}_{2}$ analysers (Servomex 4100; Servomex Group Ltd, Crowborough, East Sussex, UK). Data acquisition was performed using custombuilt interfaces (IDEE Maastricht University, Maastricht, The Netherlands), a computer (Apple Macintosh, Cupertino, CA, USA), and graphical programming environment (Labview; National Instruments, Austin, TX, USA).

Energy expenditure and carbohydrate, fat and protein oxidation were calculated from the measurements of $\mathrm{O}_{2}$ consumption, $\mathrm{CO}_{2}$ production, and urinary $\mathrm{N}$ excretion, using the formula of Brouwer ${ }^{(36)}$. Energy expenditure and $24 \mathrm{~h}$ RQ were measured from 08.00 hours on day 2 until 07.30 hours on day 3. Sleeping metabolic rate was defined as the lowest mean energy expenditure measured over 3 consecutive $\mathrm{h}$ between 00.00 and 06.00 hours. From the second voiding on day 2 until the first voiding on day 3, $24 \mathrm{~h}$ urine was collected. Samples were collected in containers with $10 \mathrm{ml} \mathrm{H}_{2} \mathrm{SO}_{4}$ to prevent $\mathrm{N}$ loss through evaporation. Volume and $\mathrm{N}$ concentration were measured, the latter using a nitrogen analyser (Elemental Analyzer; CHN-O-Rapid, Heraeus, Wellesley, MA, USA).

$\beta$-Hydroxybutyrate. A blood sample was obtained after an overnight fast at 08.00 hours on day 3 and mixed in an EDTA tube, centrifuged at $4^{\circ} \mathrm{C}$ for $10 \mathrm{~min}$ at $3000 \mathrm{rpm}$. Plasma was stored at $-80^{\circ} \mathrm{C}$ until analysis. The $\beta$-hydroxybutyrate concentration was measured with the method of Moore et al. using a semi-automated centrifugal spectrophotometer (Cobas Fara; Roche Diagnostics, Basel, Switzerland) ${ }^{(37)}$.

Body composition. Body composition was determined by the three-compartment model, using the hydrodensitometry and ${ }^{2} \mathrm{H}$ dilution $\left({ }^{2} \mathrm{H}_{2} \mathrm{O}\right)$ technique ${ }^{(38,39)}$ and was calculated using the combined equation of $\mathrm{Siri}^{(40)}$.

\section{Statistical analysis}

Data are presented as mean values and standard deviations. A repeated-measures ANOVA was used to determine possible differences in appetite, energy expenditure, RQ and $\beta$-hydroxybutyrate concentration between the HP and the NP diet and between the HP-0C and the NP-g diet, respectively. A Mann-Whitney $U$ test was used to determine differences in appetite, energy expenditure, RQ and $\beta$-hydroxybutyrate concentration between the NP-g and the NP diet and between the HP-OC and the HP diet, respectively. In addition, a MannWhitney $U$ test was used to determine differences in the difference between the HP and the NP diet and the difference between the HP-0C and the NP-g diet in appetite, energy expenditure, RQ and $\beta$-hydroxybutyrate concentration. 
Table 2. Composition of the meals, average intake per food item ( $\mathrm{g}$ and kJ), macronutrient intake and energy density of the normal-protein (NP), high-protein (HP), normal-protein (NP-g) and the high-protein, carbohydrate-free (HP-OC) diet*

\begin{tabular}{|c|c|c|c|c|c|c|c|c|c|c|c|c|c|}
\hline $\begin{array}{l}\text { Diet and } \\
\text { meal }\end{array}$ & & $\begin{array}{l}\text { Wt of } \\
\text { item (g) }\end{array}$ & $\begin{array}{l}\text { Energy } \\
\text { content of } \\
\text { item }(\mathrm{kJ})\end{array}$ & $\begin{array}{l}\text { Protein } \\
\text { content } \\
\text { (g) }\end{array}$ & $\begin{array}{l}\mathrm{CHO} \\
\text { content } \\
\text { (g) }\end{array}$ & $\begin{array}{l}\text { Fat } \\
\text { content } \\
\text { (g) }\end{array}$ & $\begin{array}{c}\text { Diet and } \\
\text { meal }\end{array}$ & & $\begin{array}{l}\text { Wt of } \\
\text { item } \\
\text { (g) }\end{array}$ & $\begin{array}{l}\text { Energy } \\
\text { content of } \\
\text { item }(\mathrm{kJ})\end{array}$ & $\begin{array}{l}\text { Protein } \\
\text { content } \\
\text { (g) }\end{array}$ & $\begin{array}{l}\mathrm{CHO} \\
\text { content } \\
\text { (g) }\end{array}$ & $\begin{array}{c}\text { Fat } \\
\text { content } \\
\text { (g) }\end{array}$ \\
\hline \multicolumn{7}{|l|}{ NP } & \multicolumn{7}{|l|}{$\mathrm{HP}$} \\
\hline \multirow[t]{9}{*}{ Breakfast } & Whole-wheat bread & 94 & 900 & 8 & 40 & 1 & \multirow[t]{9}{*}{ Breakfast } & Whole-wheat bread & 65 & 712 & 6 & 29 & 2 \\
\hline & Low-fat margarine & 24 & 333 & 0 & 0 & 8 & & Margarine & 9 & 296 & 0 & 0 & 7 \\
\hline & Chocolate spread & 18 & 446 & 1 & 10 & 6 & & Chicken filet & 46 & 331 & 14 & 0 & 2 \\
\hline & Confiture & 24 & 251 & 0 & 14 & 0 & & Milk & 280 & 579 & 10 & 13 & 4 \\
\hline & $\begin{array}{l}\text { Coffee (decaffeinated) } \\
\text { or tea }\end{array}$ & 250 & 0 & 0 & 0 & 0 & & & & & & & \\
\hline & Energy density of meal & & & & & & & Energy density of meal & & & & & \\
\hline & $(\mathrm{kJ} / \mathrm{g})$ & & & $4 \cdot 7$ & & & & $(\mathrm{~kJ} / \mathrm{g})$ & & & $4 \cdot 8$ & & \\
\hline & $\%$ of energy from & & & & & & & $\%$ of energy from & & & & & \\
\hline & $\begin{array}{l}\text { protein, } \mathrm{CHO} \text { and fat } \\
\text { in meal }\end{array}$ & & & 9/58/31 & & & & $\begin{array}{l}\text { protein, } \mathrm{CHO} \text { and fat } \\
\text { in meal }\end{array}$ & & & $29 / 39 / 31$ & & \\
\hline \multirow[t]{13}{*}{ Lunch } & Soup (bouillon) & 200 & 20 & 0 & 1 & 0 & \multirow[t]{13}{*}{ Lunch } & Soup (bouillon) & 200 & 20 & 0 & 1 & 0 \\
\hline & Whole-wheat bread & 147 & 1403 & 12 & 62 & 2 & & Whole-wheat bread & 104 & 1138 & 9 & 47 & 3 \\
\hline & Low-fat margarine & 25 & 353 & 0 & 0 & 9 & & Soya milk & 178 & 326 & 6 & 3 & 4 \\
\hline & Chocolate spread & 30 & 756 & 1 & 17 & 11 & & Tomato & 20 & 18 & 0 & 0 & 0 \\
\hline & Cheese & 25 & 276 & 9 & 0 & 3 & & Cucumber & 27 & 10 & 0 & 0 & 0 \\
\hline & Lettuce & 118 & 22 & 1 & 0 & 0 & & Feta cheese & 63 & 896 & 12 & 4 & 15 \\
\hline & Cucumber & 41 & 15 & 0 & 1 & 0 & & Salad dressing & 25 & 250 & 0 & 3 & 5 \\
\hline & Olive oil & 5 & 181 & 0 & 0 & 5 & & Tuna in water & 111 & 593 & 29 & 0 & 2 \\
\hline & Grape juice & 295 & 840 & 1 & 47 & 0 & & Fruit yoghurt & 198 & 631 & 8 & 27 & 0 \\
\hline & Energy density of meal & & & & & & & Energy density of meal & & & & & \\
\hline & $(\mathrm{kJ} / \mathrm{g})$ & & & 4.4 & & & & $(\mathrm{~kJ} / \mathrm{g})$ & & & $4 \cdot 2$ & & \\
\hline & $\%$ of energy from & & & & & & & $\%$ of energy from & & & & & \\
\hline & $\begin{array}{l}\text { protein, } \mathrm{CHO} \text { and fat } \\
\text { in meal }\end{array}$ & & & $11 / 58 / 31$ & & & & $\begin{array}{l}\text { protein, } \mathrm{CHO} \text { and fat } \\
\text { in meal }\end{array}$ & & & $31 / 39 / 30$ & & \\
\hline \multirow[t]{16}{*}{ Dinner } & Soup (bouillon) & 200 & 20 & 0 & 1 & 0 & \multirow[t]{16}{*}{ Dinner } & Soup (bouillon) & 200 & 20 & 0 & 1 & 0 \\
\hline & Chinese noodle dish & 332 & 2594 & 18 & 80 & 22 & & Rice dish with ham & 286 & 2966 & 55 & 74 & 16 \\
\hline & Lettuce & 85 & 16 & 1 & 0 & 0 & & Soya milk & 295 & 540 & 11 & 6 & 6 \\
\hline & Cucumber & 35 & 13 & 0 & 1 & 0 & & Muesli bar & 18 & 340 & 1 & 10 & 4 \\
\hline & Olive oil & 7 & 253 & 0 & 0 & 6 & & Sugar-free syrup & 175 & 0 & 0 & 0 & 0 \\
\hline & Fruit cocktail & 170 & 516 & 1 & 28 & 0 & & & & & & & \\
\hline & Grape juice & 165 & 464 & 0 & 26 & 0 & & & & & & & \\
\hline & Energy density of meal & & & & & & & Energy density of meal & & & & & \\
\hline & $(\mathrm{kJ} / \mathrm{g})$ & & & 3.9 & & & & $(\mathrm{~kJ} / \mathrm{g})$ & & & 4.0 & & \\
\hline & $\%$ of energy from & & & & & & & $\%$ of energy from & & & & & \\
\hline & protein, $\mathrm{CHO}$ and fat & & & & & & & protein, $\mathrm{CHO}$ and fat & & & & & \\
\hline & in meal & & & $10 / 62 / 28$ & & & & in meal & & & $32 / 41 / 27$ & & \\
\hline & Energy density of diet & & & & & & & Energy density of diet & & & & & \\
\hline & $(\mathrm{kJ} / \mathrm{g})$ & & & $4 \cdot 2$ & & & & $(\mathrm{~kJ} / \mathrm{g})$ & & & $4 \cdot 2$ & & \\
\hline & $\%$ of energy from & & & & & & & $\%$ of energy from & & & & & \\
\hline & protein, $\mathrm{CHO}$ and fat & & & $10 / 60 / 30$ & & & & protein, $\mathrm{CHO}$ and fat & & & & & \\
\hline \multirow{5}{*}{$\begin{array}{l}\text { NP-g } \\
\text { Breakfast }\end{array}$} & & & & $10 / 00 / 30$ & & & \multicolumn{7}{|l|}{$\mathrm{HP}-\mathrm{OC}$} \\
\hline & Whole-wheat bread & 89 & 853 & 8 & 38 & 1 & Breakfast & Boiled eggs & 117 & 745 & 15 & 0 & 12 \\
\hline & Low-fat margarine & 22 & 315 & 0 & 0 & 8 & & Bacon & 66 & 1111 & 12 & 0 & 22 \\
\hline & & & & & & & & Coffee (decaffeinated) & & & & & \\
\hline & Chocolate spread & 17 & 423 & 1 & 10 & 6 & & or tea & 250 & 0 & 0 & 0 & 0 \\
\hline
\end{tabular}


NS British Journal of Nutrition

Table 2. Continued

\begin{tabular}{|c|c|c|c|c|c|c|c|c|c|c|c|c|c|}
\hline $\begin{array}{l}\text { Diet and } \\
\text { meal }\end{array}$ & & $\begin{array}{c}\text { Wt of } \\
\text { item }(g)\end{array}$ & $\begin{array}{l}\text { Energy } \\
\text { content of } \\
\text { item (kJ) }\end{array}$ & $\begin{array}{l}\text { Protein } \\
\text { content } \\
\text { (g) }\end{array}$ & $\begin{array}{c}\mathrm{CHO} \\
\text { content } \\
(\mathrm{g})\end{array}$ & $\begin{array}{c}\text { Fat } \\
\text { content } \\
\text { (g) }\end{array}$ & $\begin{array}{c}\text { Diet and } \\
\text { meal }\end{array}$ & & $\begin{array}{c}\text { Wt of } \\
\text { item } \\
(\mathrm{g})\end{array}$ & $\begin{array}{l}\text { Energy } \\
\text { content of } \\
\text { item (kJ) }\end{array}$ & $\begin{array}{l}\text { Protein } \\
\text { content } \\
\text { (g) }\end{array}$ & $\begin{array}{l}\mathrm{CHO} \\
\text { content } \\
(\mathrm{g})\end{array}$ & $\begin{array}{c}\text { Fat } \\
\text { content } \\
(\mathrm{g})\end{array}$ \\
\hline & $\begin{array}{l}\text { Confiture } \\
\text { Coffee (decaffeinated) } \\
\text { or tea } \\
\text { Energy density of meal } \\
(\mathrm{kJ} / \mathrm{g}) \\
\% \text { of energy from } \\
\text { protein, } \mathrm{CHO} \text { and fat } \\
\text { in meal }\end{array}$ & $\begin{array}{r}22 \\
250\end{array}$ & 238 & $\begin{array}{c}0 \\
0 \\
4.6 \\
9 / 59 / 32\end{array}$ & 13 & $\begin{array}{l}0 \\
0\end{array}$ & & $\begin{array}{l}\text { Energy density of meal } \\
(\mathrm{kJ} / \mathrm{g}) \\
\% \text { of energy from } \\
\text { protein, } \mathrm{CHO} \text { and fat } \\
\text { in meal }\end{array}$ & & & $\begin{array}{c}4.3 \\
27 / 0 / 73\end{array}$ & & \\
\hline Lunch & $\begin{array}{l}\text { Soup (bouillon) } \\
\text { Whole-wheat bread } \\
\text { Low-fat margarine } \\
\text { Chocolate spread } \\
\text { Cheese } \\
\text { Lettuce } \\
\text { Cucumber } \\
\text { Olive oil } \\
\text { Grape juice } \\
\text { Energy density of meal } \\
\text { (kJ/g) } \\
\% \text { of energy from } \\
\text { protein, CHO and fat } \\
\text { in meal }\end{array}$ & $\begin{array}{r}200 \\
142 \\
20 \\
26 \\
22 \\
115 \\
39 \\
7 \\
287\end{array}$ & $\begin{array}{r}20 \\
1355 \\
282 \\
655 \\
243 \\
21 \\
14 \\
242 \\
818\end{array}$ & $\begin{array}{c}0 \\
12 \\
0 \\
1 \\
7 \\
1 \\
0 \\
0 \\
1 \\
4 \cdot 3 \\
\end{array}$ & $\begin{array}{r}1 \\
60 \\
0 \\
15 \\
0 \\
0 \\
1 \\
0 \\
46\end{array}$ & $\begin{array}{r}0 \\
2 \\
7 \\
10 \\
3 \\
0 \\
0 \\
6 \\
0\end{array}$ & Lunch & $\begin{array}{l}\text { Soup (bouillon) } \\
\text { Salami } \\
\text { Tuna in oil } \\
\text { Garden cress } \\
\text { French cheese } \\
\text { Lettuce } \\
\text { Mushrooms } \\
\text { Olive oil } \\
\text { Sugar-free syrup } \\
\text { Energy density of meal } \\
\text { (kJ/g) } \\
\% \text { of energy from } \\
\text { protein, CHO and fat } \\
\text { in meal }\end{array}$ & $\begin{array}{r}250 \\
55 \\
108 \\
11 \\
59 \\
103 \\
27 \\
35 \\
200\end{array}$ & $\begin{array}{r}26 \\
924 \\
924 \\
4 \\
494 \\
19 \\
25 \\
1266 \\
0\end{array}$ & $\begin{array}{r}0 \\
11 \\
29 \\
0 \\
13 \\
1 \\
1 \\
0 \\
0 \\
4 \cdot 3 \\
\\
\\
28 / 0 / 71\end{array}$ & $\begin{array}{l}1 \\
0 \\
0 \\
0 \\
0 \\
0 \\
0 \\
0 \\
0\end{array}$ & $\begin{array}{r}0 \\
18 \\
10 \\
0 \\
6 \\
0 \\
0 \\
32 \\
0\end{array}$ \\
\hline Dinner & $\begin{array}{l}\text { Soup (bouillon) } \\
\text { Chinese noodle dish } \\
\text { Lettuce } \\
\text { Cucumber } \\
\text { Olive oil } \\
\text { Fruit cocktail } \\
\text { Grape juice } \\
\\
\\
\text { Energy density of meal } \\
\text { (kJ/g) } \\
\% \text { of energy from } \\
\text { protein, } \mathrm{CHO} \text { and fat } \\
\text { in meal } \\
\text { Energy density of diet } \\
\quad(\mathrm{kJ} / \mathrm{g}) \\
\% \text { of energy from } \\
\text { protein, } \mathrm{CHO} \text { and fat } \\
\text { in diet }\end{array}$ & $\begin{array}{r}200 \\
303 \\
83 \\
34 \\
7 \\
165 \\
175\end{array}$ & $\begin{array}{r}20 \\
2368 \\
19 \\
12 \\
253 \\
502 \\
498\end{array}$ & $\begin{array}{c}3 \cdot 8 \\
10 / 62 / 28 \\
4 \cdot 1 \\
\\
10 / 60 / 30\end{array}$ & $\begin{array}{r}1 \\
73 \\
0 \\
1 \\
0 \\
27 \\
28\end{array}$ & $\begin{array}{r}0 \\
20 \\
0 \\
0 \\
6 \\
0 \\
0\end{array}$ & Dinner & $\begin{array}{l}\text { Soup (bouillon) } \\
\text { Chicken meat } \\
\text { Tuna in oil } \\
\text { Garden cress } \\
\text { Cheese } \\
\text { Lettuce } \\
\text { Mushrooms } \\
\text { Olive oil } \\
\text { Sugar-free syrup } \\
\text { Energy density of meal } \\
\text { ( } \mathrm{kJ} / \mathrm{g}) \\
\% \text { of energy from } \\
\text { protein, } \mathrm{CHO} \text { and fat } \\
\text { in meal } \\
\text { Energy density of diet } \\
\text { ( } \mathrm{kJ} / \mathrm{g} \text { ) } \\
\% \text { of energy from } \\
\text { protein, } \mathrm{CHO} \text { and fat } \\
\text { in diet }\end{array}$ & $\begin{array}{r}250 \\
65 \\
108 \\
11 \\
54 \\
125 \\
32 \\
34 \\
250\end{array}$ & $\begin{array}{r}26 \\
474 \\
924 \\
4 \\
915 \\
23 \\
30 \\
1230 \\
0\end{array}$ & $\begin{array}{r}0 \\
20 \\
29 \\
0 \\
14 \\
1 \\
2 \\
0 \\
0 \\
3 \cdot 9 \\
\\
33 / 0 / 67 \\
\\
4 \cdot 1 \\
\\
30 / 0 / 70\end{array}$ & $\begin{array}{l}1 \\
0 \\
0 \\
0 \\
0 \\
0 \\
0 \\
0 \\
0\end{array}$ & $\begin{array}{r}0 \\
3 \\
10 \\
0 \\
17 \\
0 \\
0 \\
31 \\
0\end{array}$ \\
\hline
\end{tabular}

* Macronutrient composition of the food items was based on food tables. The amounts of food items were adjusted to subject-specific energy requirements; the data shown here are based on average energy intake of 9.65 (sD 0.7 ) $\mathrm{MJ} / \mathrm{d}$ in group 1 (NP and HP) and 9.14 (SD 1.3) MJ/d in group 2 (NP-g and HP-OC). 
A repeated-measures ANOVA was used to test whether macronutrient balances were significantly different from zero and whether macronutrient balances were different between the HP diet and the NP diet and between the HP-0C diet and the NP-g diet. A Mann-Whitney $U$ test was used to test whether macronutrient balances were different between the NP-g diet and the NP diet and between the HP-0C diet and the HP diet. Possible relationships between macronutrient oxidation and appetite profile were studied using regression analyses. $P<0.05$ was regarded as statistically significant. Statistical procedures were performed using StatView 5.0 (1998; SAS Institute, Inc., Cary, NC, USA).

\section{Results}

There were no differences between the NP diet and the NP-g diet in appetite profile, energy expenditure, RQ or $\beta$-hydroxybutyrate concentration (Table 3 ). Thus, the glycogen-lowering exercise test did not affect these parameters. Moreover, differences between these variables did not differ between men and women; therefore the data were analysed together.

\section{Appetite profile}

Hunger was $10 \%$ lower after the HP diet than after the NP diet $(P<0.05$; Table 3$)$ and was $33 \%$ lower after the HP-0C diet than after the NP-g diet $(P<0 \cdot 001)$. There was no difference in hunger between the NP-g and the NP diet, whereas hunger was $27 \%$ lower after the HP-OC diet than after the HP diet ( $z$-score: $4 \cdot 1 ; P<0 \cdot 01)$. The $\Delta$ hunger between the HP-0C and the NP-g diet was larger than the $\Delta$ hunger between the HP and the NP diet ( $z$-score: $5 \cdot 1 ; P<0 \cdot 01)$.

Fullness was $21 \%$ higher after the HP diet than after the NP diet $(P<0.05)$ and was $28 \%$ higher after the HP-0C diet than after the NP-g diet $(P<0 \cdot 001)$. There was no difference in fullness between the NP-g and the NP diet or between the HP-0C and the HP diet. The $\Delta$ fullness between the HP-0C and the NP-g diet was higher than the $\Delta$ fullness between the HP and the NP diet ( $z$-score: $5 \cdot 1 ; P<0 \cdot 01$ ).

Patterns of hunger and fullness ratings over time were similar between all conditions (data not shown). Hunger and fullness ratings were continuously lower and higher, respectively, after HP $v$. NP, HP-0C v. NP-g and HP-0C v. HP with significant differences at various time points.

\section{Energy intake, expenditure and balance}

Energy intake was not different between group 1 and 2; 9.65 $(\mathrm{SD} 0 \cdot 70) \mathrm{MJ} / \mathrm{d}$ in group 1 and 9.14 (SD 1.30) $\mathrm{MJ} / \mathrm{d}$ in group 2, respectively (Table 3 ; NS).

Energy expenditure was $4 \%$ higher after the HP diet than after the NP diet $(P<0.05$; Table 3$)$ and tended to be higher after the HP-0C diet than after the NP-g diet $(P=0 \cdot 07)$. There was no difference in energy expenditure between the NP-g and the NP diet or between the HP-0C and the HP diet. The $\Delta$ energy expenditure between the HP-0C and the $\mathrm{NP}-\mathrm{g}$ diet was not different from the $\Delta$ energy expenditure between the HP and the NP diet.

Energy balance was not different from zero after the HP diet, whereas the subjects were slightly in positive energy balance after the NP diet $(P<0 \cdot 05$; Table 3$)$. Energy balance was not different from zero both after the HP-0C diet and the NP-g diet. The energy balance was not different between the NP-g diet and the NP diet or between the HP-0C diet and the HP diet.

\section{Respiratory quotient}

The RQ was lower after the HP diet than after the NP diet $(P<0.01$; Table 3$)$ and was lower after the HP-0C diet than after the NP-g diet $(P<0 \cdot 001)$. There was no difference in RQ between the NP-g and the NP diet whereas the RQ was lower after the HP-OC diet than after the HP diet ( $z$-score: $4.9 ; P<0.01)$. The $\Delta \mathrm{RQ}$ between the HP-0C and the NP-g diet was larger than the $\Delta \mathrm{RQ}$ between the HP and the NP diet ( $z$-score: $5 \cdot 3 ; P<0 \cdot 001)$.

\section{$\beta$-Hydroxybutyrate}

The $\beta$-hydroxybutyrate concentration was higher after the HP diet than after the NP diet $(P<0.05$; Table 3$)$ and was higher after the HP-0C diet than after the NP-g diet $(P<0 \cdot 001)$. There was no difference in $\beta$-hydroxybutyrate concentration between the NP-g and the NP diet, whereas the $\beta$-hydroxybutyrate concentration was higher after the HP-0C diet than after the HP diet ( $z$-score: $5 \cdot 8 ; P<0.001$ ). The $\Delta \beta$-hydroxybutyrate concentration between the HP-0C and the NP-g diet was larger than the $\Delta \beta$-hydroxybutyrate concentration between the HP and the NP diet ( $z$-score: $5 \cdot 3 ; P<0 \cdot 001$ ).

\section{Macronutrient balances}

Protein, carbohydrate and fat intake, oxidation and balance are shown in Table 4.

After the HP diet, protein balance was positive and fat balance was negative $(P<0 \cdot 01)$. After the NP-g diet, protein and fat balance were negative $(P<0.05$ and $P<0.01)$ and carbohydrate balance was positive $(P<0 \cdot 01)$. After the HP$0 \mathrm{C}$ diet, protein balance was positive $(P<0.01)$ and carbohydrate balance was negative $(P<0 \cdot 01)$. Protein and fat balance was different between HP and NP $(P<0.01$ and $P<0.001)$, whereas protein, carbohydrate and fat balance was different between HP-0C and NP-g $(P<0.001$ for all). Protein, carbohydrate and fat balance was different between NP-g and NP $(P<0.001$ for all $)$ and carbohydrate and fat balance was different between HP-0C and HP $(P<0.001$ for all). There was no relationship between macronutrient oxidation and appetite profile.

\section{Discussion}

The presence or absence of a normal proportion of carbohydrates, and consequently differences in the proportion of fat, in a relatively high-protein diet significantly affected the metabolic targets appetite suppression and fat oxidation in healthy normal-weight subjects who were in energy balance and were studied under highly controlled conditions. Both males and females were included to conduct a study that is relevant for a larger part of the population. Moreover, differences between the variables were not different between men and women. Yet, this mixed-sex population may have increased variance in outcomes, since sex-specific effects of similar diets have been shown before in that appetite-related 
Table 3. Appetite profile, energy intake (MJ/d), energy expenditure $(\mathrm{MJ} / \mathrm{d})$, energy balance $(\mathrm{MJ} / \mathrm{d}), 24 \mathrm{~h}$ respiratory quotient $(\mathrm{RQ})$ and $\beta$-hydroxybutyrate concentration $(\mu \mathrm{mol} / \mathrm{l})$ after a high protein $(\mathrm{HP})$, normal-protein (NP), high-protein, carbohydrate-free (HP-0C), or a normal-protein (NP-g) diet for $2 \mathrm{~d}$ in twenty-two (NP and HP) and twenty-three (NP-g and HP-0C) healthy subjects (males and females)†

(Mean values and standard deviations)

\begin{tabular}{|c|c|c|c|c|c|c|c|c|c|c|c|c|c|c|c|c|c|}
\hline & \multicolumn{2}{|c|}{ HP } & \multicolumn{2}{|c|}{ NP } & \multicolumn{2}{|c|}{$\Delta \mathrm{HP}-\mathrm{NP}$} & \multicolumn{3}{|c|}{ HP-OC } & \multicolumn{2}{|c|}{ NP-g } & \multicolumn{2}{|c|}{$\Delta$ HP-OC-NP-g } & \multirow[b]{2}{*}{$\begin{array}{l}\Delta \text { HP-OC } \\
\text { v. NP-g: } \\
P \ddagger\end{array}$} & \multirow[b]{2}{*}{$\begin{array}{l}\text { NP-g } v \text {. } \\
\text { NP, } \\
Z \text {-score: } \\
P \S\end{array}$} & \multirow[b]{2}{*}{$\begin{array}{l}\mathrm{HP}-0 \mathrm{C} v \text {. } \\
\mathrm{HP}, z \text {-score } \\
\text { and } P \S\end{array}$} & \multirow{2}{*}{$\begin{array}{l}\Delta \mathrm{HP}-0 \mathrm{C} \\
-\mathrm{NP}-\mathrm{g} \\
v . \Delta \mathrm{HP} \\
-\mathrm{NP} \\
z \text {-score } \\
\text { and } P \S\end{array}$} \\
\hline & Mean & SD & Mean & SD & Mean & SD & $\begin{array}{l}\mathrm{HP} v \text {. } \\
\text { NP: } \\
P \neq\end{array}$ & Mean & SD & Mean & SD & Mean & SD & & & & \\
\hline \multicolumn{18}{|l|}{ Hunger } \\
\hline $\begin{array}{l}\text { Fullness } \\
(\text { mm VAS } \times 24 \mathrm{~h}) \\
\text { Energy intake }\end{array}$ & 989 & 203 & 815 & 198 & 174 & 43 & $<0.05$ & 998 & 258 & 782 & 196 & 216 & 54 & $<0.001$ & NS & NS & $4.8(<0.01)$ \\
\hline $\begin{array}{l}(\mathrm{MJ} / \mathrm{d}) \\
\text { Energy expenditure }\end{array}$ & 9.65 & 0.70 & 9.65 & 0.70 & & & NS & $9 \cdot 14$ & $1 \cdot 30$ & $9 \cdot 14$ & 1.30 & & & NS & NS & NS & \\
\hline $\begin{array}{l}(\mathrm{MJ} / \mathrm{d}) \\
\text { Energy balance }\end{array}$ & $9 \cdot 75$ & $0 \cdot 70$ & 9.35 & 0.70 & 0.40 & 0.46 & $<0.05$ & $9 \cdot 23$ & $1 \cdot 10$ & $9 \cdot 04$ & $1 \cdot 20$ & 0.18 & 0.44 & NS $(P=0.07)$ & NS & NS & NS \\
\hline$(\mathrm{MJ} / \mathrm{d}) \|$ & -0.10 & 0.36 & $0.30^{*}$ & 0.40 & 0.40 & 0.38 & $<0.05$ & -0.09 & 0.47 & $0 \cdot 10$ & 0.38 & 0.19 & 0.45 & NS & NS & NS & NS \\
\hline $\begin{array}{l}24 \mathrm{~h} \mathrm{RQ} \\
\beta \text {-Hydroxybutyrate }\end{array}$ & 0.81 & 0.02 & 0.86 & 0.02 & -0.05 & 0.00 & $<0.01$ & 0.76 & 0.01 & 0.85 & 0.02 & -0.09 & 0.00 & $<0.001$ & NS & $4.9(<0.01)$ & $5.3(<0.001)$ \\
\hline$(\mu \mathrm{mol} / \mathrm{l})$ & 332 & 102 & 228 & 88 & 104 & 42 & $<0.05$ & 1349 & 653 & 234 & 226 & 1115 & 627 & $<0.001$ & NS & $5.8(<0.001)$ & $5.3(<0.001)$ \\
\hline
\end{tabular}

VAS, visual analogue scale.

*Energy balance $(\mathrm{MJ} / \mathrm{d})$ was significantly different from zero $(P<0.05$; repeated-measures ANOVA).

† The macronutrient composition of NP was 10,60 and $30 \%$ of energy (En\%) from protein, carbohydrate and fat; for HP it was 30,40 and 30 En\%; for NP-g it was 10,60 and $30 \mathrm{En} \%$; for HP-0C it was 30,0 and $70 \mathrm{En} \%$.

$\ddagger$ Repeated-measures ANOVA for comparison of HP $v$. NP and HP-OC $v$. NP-g.

$\S$ Mann-Whitney $U$ test for comparison of NP-g v. NP, HP-OC v. HP, and $\triangle$ HP-OC - NP-g v. $\Delta$ HP - NP.

$\|$ Energy balance $(M J / d)=$ energy intake $(M J / d)$ - energy expenditure $(M J / d)$. 
Table 4. Macronutrient intake, oxidation and balance (all $\mathrm{MJ} / \mathrm{d}$ ) after a normal-protein (NP), high-protein (HP), normal-protein (NP-g) or a high-protein, carbohydrate-free (HP-0C) diet for 2d in twenty-two (NP and HP) and twenty-three (NP-g and HP-OC) healthy normal-weight subjects (males and females) $\dagger$

(Mean values and standard deviations)

\begin{tabular}{|c|c|c|c|c|c|c|c|c|c|}
\hline & \multicolumn{2}{|c|}{ Intake } & \multicolumn{2}{|c|}{ Expenditure/oxidation } & \multicolumn{2}{|c|}{ Balanceł } & \multirow[b]{2}{*}{ ANOVA§ } & \multirow{2}{*}{$\begin{array}{l}\mathrm{HP} v . \mathrm{NP} \text { and } \\
\mathrm{HP}-\mathrm{OC} \text { v. NP-gll}\end{array}$} & \multirow{2}{*}{$\begin{array}{l}\text { NP-g v. NP and } \\
\text { HP-OC v. HPq }\end{array}$} \\
\hline & Mean & SD & Mean & SD & Mean & SD & & & \\
\hline \multicolumn{10}{|l|}{ NP } \\
\hline Protein (MJ/d) & 0.98 & 0.14 & 0.97 & 0.24 & 0.01 & 0.23 & & & \\
\hline Carbohydrates (MJ/d) & $5 \cdot 76$ & 0.73 & 5.43 & 0.85 & 0.33 & 0.58 & & & \\
\hline Fat $(\mathrm{MJ} / \mathrm{d})$ & $2 \cdot 90$ & 0.39 & $2 \cdot 84$ & 0.43 & 0.06 & $0 \cdot 21$ & & & \\
\hline \multicolumn{10}{|l|}{ HP } \\
\hline Protein $(\mathrm{MJ} / \mathrm{d})$ & 2.96 & 0.35 & 2.45 & 0.35 & 0.51 & 0.22 & ** & $* *$ & \\
\hline Carbohydrates $(\mathrm{MJ} / \mathrm{d})$ & 3.87 & 0.59 & 3.65 & 0.71 & 0.22 & 0.24 & & & \\
\hline Fat $(\mathrm{MJ} / \mathrm{d})$ & $2 \cdot 82$ & 0.41 & 3.62 & 0.68 & -0.80 & 0.45 & ** & $* * *$ & \\
\hline \multicolumn{10}{|l|}{ NP-g } \\
\hline Protein $(\mathrm{MJ} / \mathrm{d})$ & 0.92 & 0.13 & $1 \cdot 12$ & 0.28 & -0.20 & 0.20 & * & & $\star \star \star \star$ \\
\hline Carbohydrates $(\mathrm{MJ} / \mathrm{d})$ & 5.52 & 0.70 & 4.41 & 0.89 & $1 \cdot 11$ & 0.69 & ** & & $\star \star \star *$ \\
\hline Fat $(\mathrm{MJ} / \mathrm{d})$ & $2 \cdot 74$ & 0.39 & 3.54 & 0.69 & -0.80 & 0.62 & ** & & *** \\
\hline \multicolumn{10}{|l|}{ HP-OC } \\
\hline Protein (MJ/d) & 2.73 & 0.37 & 2.08 & 0.32 & 0.65 & 0.24 & ** & 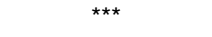 & \\
\hline Carbohydrates $(\mathrm{MJ} / \mathrm{d})$ & 0.03 & 0.08 & 1.01 & 0.51 & -0.97 & 0.51 & ** & $\star \star \star$ &  \\
\hline Fat $(\mathrm{MJ} / \mathrm{d})$ & $6 \cdot 40$ & 0.88 & $6 \cdot 16$ & 0.85 & 0.24 & 0.60 & & $\star * *$ & $\star \star * *$ \\
\hline
\end{tabular}

${ }^{\star} P<0.05,{ }^{* *} P<0.01,{ }^{* * *} P<0.001$

†The macronutrient composition of NP was 10, 60 and $30 \%$ of energy (En\%) from protein, carbohydrate and fat; for $\mathrm{HP}$ it was 30,40 and $30 \mathrm{En} \%$; for NP-g it was 10,60 and $30 \mathrm{En} \%$; for $\mathrm{HP}-\mathrm{OC}$ it was 30,0 and $70 \mathrm{En} \%$. $\ddagger$ Macronutrient balance $(\mathrm{MJ} / \mathrm{d})=$ macronutrient intake $(\mathrm{MJ} / \mathrm{d})$ - macronutrient oxidation $(\mathrm{MJ} / \mathrm{d})$.

$\S$ Repeated-measures ANOVA for macronutrient balance was different from zero.

Repeated-measures ANOVA for comparison of macronutrient balance HP v. NP and HP-OC v. NP-g.

I Mann-Whitney $U$ test for comparison of NP-g $v$. NP and HP-OC $v$. HP. 
effects were larger in women than in men, whereas energy metabolism-related effects were larger in men than in women ${ }^{(41)}$. Here, due to the limited number of subjects from the same sex, these differences may not have appeared. On the other hand, the differences due to the diets were that large, that these may have dominated any possible sex differences in these variables.

It is impossible to determine whether the observed effects of the HP-0C diet are due to a lack of carbohydrates or to elevated fat levels. Because the maximal protein content in a high-protein diet in energy balance is limited ${ }^{(21)}$, the proportion of fat in a high-protein, low-carbohydrate diet always will be relatively high. The observed effects may be due to the low carbohydrate content as well as the high fat content, promoting together with a relatively high protein content a high fat oxidation and elevated $\beta$-hydroxybutyrate concentration.

Suppression of appetite was significantly affected by the absence of a normal proportion of carbohydrates and the proportion of fat in a high-protein diet. Coinciding with the reduced appetite there was an increased dietary fat oxidation after the HP diet compared with the NP diet and an even greater fat oxidation after the HP-0C diet. Inhibition of dietary fat oxidation has been shown to increase food intake ${ }^{(42,43)}$, whereas increased fatty acid oxidation is suggested to reduce appetite $^{(44-46)}$. This is likely to be due to stimulation of carnitine palmitoyl transferase-1, a catalyst of the rate-limiting step in mitochondrial fatty acid oxidation, which has been shown to inhibit eating ${ }^{(44)}$. A greater fat oxidation together with a lower appetite was for instance also observed in human subjects that consumed diacylglycerols instead of $\mathrm{TAG}^{(47)}$. Increased fat oxidation when carbohydrate availability is low and fat availability high results in the production of ketone bodies, i.e. $\beta$-hydroxybutyrate ${ }^{(19)}$, as was also observed in the present study. The $\beta$-hydroxybutyrate concentration after the HP diet was increased but within the normal range ${ }^{(47)}$. However, after the HP-0C diet the $\beta$-hydroxybutyrate concentration was increased dramatically, to a level comparable with that after weight $\operatorname{loss}{ }^{(18)}$. In rats, intracerebroventricular infusion or subcutaneous injection of $\beta$-hydroxybutyrate reduced food intake ${ }^{(48,49)}$. Higher $\beta$-hydroxybutyrate concentrations coinciding with reduced appetite in human subjects also have been reported ${ }^{(18,46,50,51)}$. Taken together, the increased dietary fat oxidation and increase in $\beta$-hydroxybutyrate concentration, i.e. a ketogenic state, is likely to contribute to the appetite-suppressive effect of high-protein, low-carbohydrate, high-fat diets. The same mechanism may play a role in a high-protein, normal-carbohydrate diet, but to a much smaller extent.

The present study also clearly shows that the presence or absence of a normal proportion of carbohydrates and the proportion of fat in a relatively high-protein diet do not affect energy expenditure differently. Therefore, the increase in energy expenditure that has been observed with high-protein diets ${ }^{(23-25)}$ is mainly due to the relatively high proportion of protein and not the presence or absence of a normal proportion of carbohydrates or the fat content.

The effects of the two types of high-protein diets were compared using two groups of subjects, without significant differences in subject characteristics. The glycogen-lowering exercise performed by the subjects in group 2 and not by those in group 1 is unlikely to have affected appetite, energy expenditure or $\beta$-hydroxybutyrate concentration, since these parameters were not different between the NP and the NP-g diet. Nevertheless, macronutrient oxidation was affected by the exercise: protein and fat balances were lower whereas carbohydrate balance was more positive after the NP-g diet compared with the NP diet. Glycogen depletion has been shown to increase rates of muscle proteolysis and branchedchain amino acid oxidation, resulting in relatively increased protein oxidation, hence a negative protein balance ${ }^{(52)}$. Regarding the positive carbohydrate balance it is likely that the surplus of carbohydrates was used to restore body glycogen stores ${ }^{(53,54)}$. Despite differences in macronutrient oxidation there was no difference in RQ between the NP diet and the NP-g diet.

The dietary fibre content was not the same in all four diets, which may have affected metabolic targets. Although there were no differences between the HP, NP and NP-g diet, the fibre content of the HP-0C diet was significantly lower than that of the other diets. Raben et al. showed that a high-fibre meal decreased diet-induced thermogenesis and fat oxidation and increased fullness ${ }^{(55)}$. However, in the study of Raben et al. the relative fibre content was much higher than in the present study $(4.7 \mathrm{~g} / \mathrm{MJ} v \text {. about } 2 \mathrm{~g} / \mathrm{MJ})^{(55)}$. Moreover, if the higher fibre content indeed increased fullness, the appetite-suppressive effect of the HP-0C diet was even more pronounced since fibre content was lower in the HP-OC diet. The increased appetite suppression and fat oxidation after the high-protein, carbohydrate-free, high-fat diet thus are not attributable to the lower fibre content of the diet. Weight and volume of the meals as well as the energy density and palatability were similar between diets; they did not explain differences in appetite ratings. Appetite suppression was shown by reduction in hunger and increased fullness, as measured by VAS. As mentioned before, it is important to study effects on metabolic targets when subjects are in energy balance. When fed in energy balance, the outcome only can be appetite profile expressed as VAS ratings and not actual energy intake ${ }^{(56)}$.

In conclusion, the presence or absence of a normal proportion of carbohydrates and the proportion of dietary fat in a relatively high-protein diet significantly affected the metabolic targets of appetite suppression and increased fat oxidation. The absence of a normal proportion of carbohydrates and a high fat content in a relatively high-protein diet induced a large increase in the concentration of $\beta$-hydroxybutyrate. An increased dietary fat oxidation and increase in the concentration of $\beta$-hydroxybutyrate, i.e. a ketogenic state, may contribute to the increased appetite suppression on a high-protein, low-carbohydrate, high-fat diet. Energy expenditure was not affected differently by the presence or absence of a normal proportion of carbohydrates and the proportion of fat in a high-protein diet.

\section{Acknowledgements}

This research was supported by the Top Institute Food and Nutrition, The Netherlands.

M. A. B. V., K. R. W., and M. S. W.-P. designed the study. M. A. B. V. and M. S. W.-P. collected and analysed the data. M. A. B. V. wrote the manuscript and K. R. W., A. J. A. H. v. V. and M. S. W.-P. contributed to the interpretation of the data and reviewed the manuscript.

None of the authors had a personal or financial conflict of interest. 


\section{References}

1. Skov AR, Toubro S, Rønn B, et al. (1999) Randomized trial on protein vs carbohydrate in ad libitum fat reduced diet for the treatment of obesity. Int $J$ Obes Relat Metab Disord 23, $528-536$

2. Layman DK, Boileau RA, Erickson DJ, et al. (2003) A reduced ratio of dietary carbohydrate to protein improves body composition and blood lipid profiles during weight loss in adult women. $J$ Nutr 133, 411-417.

3. Westerterp-Plantenga MS, Lejeune MP, Nijs I, et al. (2004) High protein intake sustains weight maintenance after body weight loss in humans. Int J Obes Relat Metab Disord 28, $57-64$.

4. Due A, Toubro S, Skov AR, et al. (2004) Effect of normal-fat diets, either medium or high in protein, on body weight in overweight subjects: a randomised 1-year trial. Int J Obes Relat Metab Disord 28, 1283-1290.

5. Noakes M, Keogh JB, Foster PR, et al. (2005) Effect of an energy-restricted, high-protein, low-fat diet relative to a conventional high-carbohydrate, low-fat diet on weight loss, body composition, nutritional status, and markers of cardiovascular health in obese women. Am J Clin Nutr 81, 1298-1306.

6. Weigle DS, Breen PA, Matthys CC, et al. (2005) A high-protein diet induces sustained reductions in appetite, ad libitum energy intake, and body weight despite compensatory changes in diurnal plasma leptin and ghrelin concentrations. Am J Clin Nutr 82, 41-48.

7. Westman EC, Yancy WS, Edman JS, et al. (2002) Effect of 6-month adherence to a very low carbohydrate diet program. Am J Med 113, 30-36.

8. Brehm BJ, Seeley RJ, Daniels SR, et al. (2003) A randomized trial comparing a very low carbohydrate diet and a calorierestricted low fat diet on body weight and cardiovascular risk factors in healthy women. $J$ Clin Endocrinol Metab 88, $1617-1623$.

9. Foster GD, Wyatt HR, Hill JO, et al. (2003) A randomized trial of a low-carbohydrate diet for obesity. $N$ Engl J Med 348, 2082-2090.

10. Samaha FF, Iqbal N, Seshadri P, et al. (2003) A lowcarbohydrate as compared with a low-fat diet in severe obesity. $N$ Engl J Med 348, 2074-2081.

11. Meckling KA, O'Sullivan C \& Saari D (2004) Comparison of a low-fat diet to a low-carbohydrate diet on weight loss, body composition, and risk factors for diabetes and cardiovascular disease in free-living, overweight men and women. $J$ Clin Endocrinol Metab 89, 2717-2723.

12. Stern L, Iqbal N, Seshadri P, et al. (2004) The effects of low-carbohydrate versus conventional weight loss diets in severely obese adults: one-year follow-up of a randomized trial. Ann Intern Med 140, 778-785.

13. Volek J, Sharman M, Gómez A, et al. (2004) Comparison of energy-restricted very low-carbohydrate and low-fat diets on weight loss and body composition in overweight men and women. Nutr Metab (Lond) 1, 13.

14. Yancy WS Jr, Olsen MK, Guyton JR, et al. (2004) A lowcarbohydrate, ketogenic diet $v$. a low-fat diet to treat obesity and hyperlipidemia: a randomized, controlled trial. Ann Intern Med 140, 769-777.

15. Johnston CS, Tjonn SL, Swan PD, et al. (2006) Ketogenic lowcarbohydrate diets have no metabolic advantage over nonketogenic low-carbohydrate diets. Am J Clin Nutr 83, 1055-1061.

16. Gardner CD, Kiazand A, Alhassan S, et al. (2007) Comparison of the Atkins, Zone, Ornish, and LEARN diets for change in weight and related risk factors among overweight premenopausal women: the A TO Z Weight Loss Study: a randomized trial. JAMA 297, 969-977.
17. Shai I, Schwarzfuchs D, Henkin Y, et al. (2008) Weight loss with a low-carbohydrate, Mediterranean, or low-fat diet. $N$ Engl J Med 359, 229-241.

18. Johnstone AM, Horgan GW, Murison SD, et al. (2008) Effects of a high-protein ketogenic diet on hunger, appetite, and weight loss in obese men feeding ad libitum. Am J Clin Nutr 87, $44-55$.

19. Robinson AM \& Williamson DH (1980) Physiological roles of ketone bodies as substrates and signals in mammalian tissues. Physiol Rev 60, 143-187.

20. Volek JS \& Westman EC (2002) Very-low-carbohydrate weight-loss diets revisited. Cleve Clin J Med 69, 849, 853, 856-848 passim.

21. Westerterp-Plantenga MS (2007) How are normal, high- or low-protein diets defined? Br J Nutr 97, 217-218.

22. Krieger JW, Sitren HS, Daniels MJ, et al. (2006) Effects of variation in protein and carbohydrate intake on body mass and composition during energy restriction: a meta-regression 1 . Am J Clin Nutr 83, 260-274.

23. Westerterp-Plantenga MS, Luscombe-Marsh N, Lejeune MPGM, et al. (2006) Dietary protein, metabolism, and body-weight regulation: dose-response effects. Int $J$ Obes (Lond) 30, Suppl. 3, S16-S23.

24. Eisenstein J, Roberts SB, Dallal G, et al. (2002) High-protein weight-loss diets: are they safe and do they work? A review of the experimental and epidemiologic data. Nutr Rev 60, 189-200.

25. Brehm BJ \& D'Alessio DA (2008) Benefits of high-protein weight loss diets: enough evidence for practice? Curr Opin Endocrinol Diabetes Obes 15, 416-421.

26. Westman EC, Feinman RD, Mavropoulos JC, et al. (2007) Low-carbohydrate nutrition and metabolism. Am J Clin Nutr 86, 276-284.

27. Schrauwen $\mathrm{P}$, van Marken Lichtenbelt WD, Saris WH, et al. (1997) Role of glycogen-lowering exercise in the change of fat oxidation in response to a high-fat diet. Am J Physiol 273, E623-E629.

28. Melanson KJ, Westerterp-Plantenga MS, Campfield LA, et al. (1999) Appetite and blood glucose profiles in humans after glycogen-depleting exercise. J Appl Physiol 87, 947-954.

29. Food and Nutrition Board (2005) Dietary Reference Intakes for Energy, Carbohydrate, Fiber, Fat, Fatty Acids, Cholesterol, Protein, and Amino Acids (Macronutrients). Washington, DC: The National Academies Press.

30. Harris JA \& Benedict FG (1918) A biometric study of basal metabolism in man. Proc Natl Acad Sci U S A 4, 370-373.

31. Westerterp KR (1999) Exercise and energy balance. In Regulation of Food Intake and Energy Expenditure, pp. 349-361 [MS Westerterp-Plantenga, AB Steffens and A Tremblay, editors]. Milan: EDRA.

32. Westerterp KR \& Kester AD (2003) Physical activity in confined conditions as an indicator of free-living physical activity. Obes Res 11, 865-868.

33. Kuipers H, Keizer HA, Brouns F, et al. (1987) Carbohydrate feeding and glycogen synthesis during exercise in man. Pflugers Arch 410, 652-656.

34. Westerterp-Plantenga MS, Rolland V, Wilson SA, et al. (1999) Satiety related to $24 \mathrm{~h}$ diet-induced thermogenesis during high protein/carbohydrate vs high fat diets measured in a respiration chamber. Eur J Clin Nutr 53, 495-502.

35. Schoffelen PF, Westerterp KR, Saris WH, et al. (1997) A dual-respiration chamber system with automated calibration. J Appl Physiol 83, 2064-2072.

36. Brouwer E (1957) On simple formulae for calculating the heat expenditure and the quantities of carbohydrate and fat oxidized in metabolism of men and animals, from gaseous exchange 
(oxygen intake and carbonic acid output) and urine-N. Acta Physiol Pharmacol Neerl 6, 795-802.

37. Moore JJ, Marcus M \& Sax SM (1982) Kinetic assay of $\beta$-hydroxybutyrate in plasma with a COBAS-BIO centrifugal analyzer. Clin Chem 28, 702-703.

38. van Marken Lichtenbelt WD, Westerterp KR \& Wouters L (1994) Deuterium dilution as a method for determining total body water: effect of test protocol and sampling time. $\mathrm{Br} J$ Nutr 72, 491-497.

39. Schoeller DA, van Santen E, Peterson DW, et al. (1980) Total body water measurement in humans with ${ }^{18} \mathrm{O}$ and ${ }^{2} \mathrm{H}$ labeled water. Am J Clin Nutr 33, 2686-2693.

40. Siri WE (1993) Body composition from fluid spaces and density: analysis of methods. 1961. Nutrition 9, 480-491, discussion 480, 492.

41. Westerterp-Plantenga MS, Lejeune MP, Smeets AJ, et al. (2009) Sex differences in energy homeostatis following a diet relatively high in protein exchanged with carbohydrate, assessed in a respiration chamber in humans. Physiol Behav 97, 414-419.

42. Kahler A, Zimmermann M \& Langhans W (1999) Suppression of hepatic fatty acid oxidation and food intake in men. Nutrition 15, 819-828.

43. Scharrer E \& Langhans W (1986) Control of food intake by fatty acid oxidation. Am J Physiol 250, R1003-R1006.

44. Langhans W (2008) Fatty acid oxidation in the energostatic control of eating - a new idea. Appetite 51, 446-451.

45. Leonhardt M \& Langhans W (2004) Fatty acid oxidation and control of food intake. Physiol Behav 83, 645-651.

46. Scharrer E (1999) Control of food intake by fatty acid oxidation and ketogenesis. Nutrition 15, 704-714.
47. Kamphuis MM, Mela DJ \& Westerterp-Plantenga MS (2003) Diacylglycerols affect substrate oxidation and appetite in humans. Am J Clin Nutr 77, 1133-1139.

48. Arase K, Fisler JS, Shargill NS, et al. (1988) Intracerebroventricular infusions of 3-OHB and insulin in a rat model of dietary obesity. Am J Physiol 255, R974-R981.

49. Fisler JS, Egawa M \& Bray GA (1995) Peripheral 3-hydroxybutyrate and food intake in a model of dietary-fat induced obesity: effect of vagotomy. Physiol Behav 58, 1-7.

50. Krotkiewski M (2001) Value of VLCD supplementation with medium chain triglycerides. Int J Obes Relat Metab Disord 25, 1393-1400.

51. Meckling KA, Gauthier M, Grubb R, et al. (2002) Effects of a hypocaloric, low-carbohydrate diet on weight loss, blood lipids, blood pressure, glucose tolerance, and body composition in free-living overweight women. Can J Physiol Pharmacol 80, $1095-1105$.

52. De Feo P, Di Loreto C, Lucidi P, et al. (2003) Metabolic response to exercise. J Endocrinol Invest 26, 851-854.

53. Acheson KJ, Schutz Y, Bessard T, et al. (1984) Nutritional influences on lipogenesis and thermogenesis after a carbohydrate meal. Am J Physiol 246, E62-E70.

54. Abbott WG, Howard BV, Christin L, et al. (1988) Short-term energy balance: relationship with protein, carbohydrate, and fat balances. Am J Physiol 255, E332-E337.

55. Raben A, Christensen NJ, Madsen J, et al. (1994) Decreased postprandial thermogenesis and fat oxidation but increased fullness after a high-fiber meal compared with a low-fiber meal. Am J Clin Nutr 59, 1386-1394.

56. Westerterp KR (2004) Diet induced thermogenesis. Nutr Metab (Lond) 1, 5. 